\title{
Expression and Purification of Transmembrane Protein MerE from Mercury-Resistant Bacillus cereus
}

\author{
Aatif Amin ${ }^{1,3 *}$, Arslan Sarwar ${ }^{3}$, Mushtaq A. Saleem ${ }^{3}$, Zakia Latif ${ }^{1}$, and Stanley J. Opella ${ }^{2}$ \\ ${ }^{1}$ Department of Microbiology and Molecular Genetics, University of the Punjab, Lahore-54590, Pakistan \\ ${ }^{2}$ Department of Chemistry and Biochemistry, University of California, San Diego, La Jolla, California 92093, USA \\ ${ }^{3}$ Department of Microbiology, Faculty of Life Sciences, University of Central Punjab, Lahore-54000, Pakistan
}

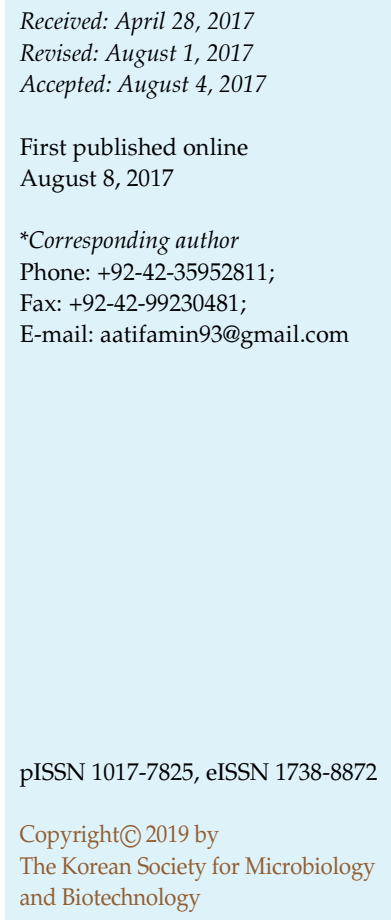

E-mail: aatifamin93@gmail.com

\section{Introduction}

Mercury pollution is a global problem due to its toxic effects on humans and animals. Anthropogenic sources and activities, e.g., the release of untreated industrial wastewater from chlor-alkali plants, metal mining and the incineration of coal, are increasing mercury pollution day by day in the environment [1]. It is evident that the cytotoxic and neurotoxic effects to humans and animals are caused by inorganic (ionic) and organic forms of mercury [2]. In Pakistan, the maximum release of mercury ( $\mathrm{kg} /$ year) is estimated as $1,625.11,2,500,21,120,1,071.79,5,779$, and 4,637.55 through extraction processes, cement industries, chlor-alkali industries, intentional uses of mercury in consumer products, waste deposition/land filling and wastewater treatment plants, respectively, indicating $36,898.77 \mathrm{~kg}$ of total cumulative release of mercury per year [3].

Bacillus sp. RC607, identified for the first time as having chromosomal resistance against mercury, was isolated from a contaminated site, Boston Harbor, USA [4]. In later studies, strain RC607-like sequences were found in 74 Bacillus spp. isolated from Minimata Bay sediment, Japan, and also in several Russian environmental bacterial isolates. It was suggested that the possible global distribution of the RC607 mer operon had occurred, as Bacillus mer operonbearing plasmids were found in several strains analyzed in the Russian study $[5,6]$.

Due to the presence of mercury in the environment and its toxic effects, microorganisms have evolved mercury 
detoxification systems to deal with mercury-containing compounds. Bacteria have the ability to detoxify the toxic form of mercury $\left(\mathrm{Hg}^{+}\right)$into the non-toxic elemental form $\left(\mathrm{Hg}^{0}\right)$ through a cytoplasmic enzyme, mercuric reductase, which is encoded by the merA gene of mer operon [7]. A lot of research analysis was done on this cytoplasmic enzyme, a member of flavin-containing, NADPH-dependent dithiol oxidoreductase that has been isolated from Gram-positive as well as Gram-negative bacteria [8]. Gram-positive and some Gram-negative bacteria also possess organomercurial lyase encoded by mer $B$ gene of mer operon which cleaves the $\mathrm{C}-\mathrm{Hg}$ bond of many mercury-containing compounds. The enzyme organomercurial lyase confers broad spectrum resistance against mercuric compounds which results in the elemental mercury $\left(\mathrm{Hg}^{0}\right)$ being diffused out of the cell [9].

Bacterial genes involved in mercury resistance are wellorganized and well-characterized into genetic elements known as mer operons. The Gram-negative bacterial mer operons contain a broad-spectrum structural gene, merE, that encodes a $\mathrm{CH}_{3} \mathrm{Hg}^{+}$and $\mathrm{Hg}_{2}^{+}$detoxification system. [10]. The merE gene, which immediately follows the merD at the downstream end of the bacterial mer operon, is frequently found in many narrow and broad-spectrum mer operons [11]. Kiyono et al., [12] have reported the transcription and translation of merE gene into a membrane protein with molecular mass of $\sim 8 \mathrm{kDa}$ in Gram-negative bacteria. Moreover, MerE protein is a methylmercury membrane transporter. This system is involved in the transportation of mercury ions across the cell membrane [12].

For structural and biochemical studies, active and properly folded forms of soluble and transmembrane proteins are essential during expression and purification procedures. For rapid screening of soluble and transmembrane proteins, fast, high-yield production has been developed by recombinant expression systems. Among bacterial, insect, yeast, mammalian and plant protein expression systems, the bacterial expression system is less expensive and fast but has two major problems. The first is that the protein-folding machinery is the least complex and the second is the formation of inclusion bodies (IBs) which are insoluble aggregates of recombinant proteins [13].

Refolding/activity of proteins from IBs is affected by several factors such as solubilization of IBs by denaturants, removal of the denaturant, and assistance of refolding by small molecule additives. The methodologies being used nowadays for refolding aggregated proteins can be divided into two major categories: chromatographic, i.e., solvent exchange by size-exclusion chromatography (SEC), on- column refolding and chaperone-assisted refolding [14] and non-chromatographic for rapid dilution of denaturants from denatured proteins, i.e., dialysis, dilution, chemical additives $\left(\mathrm{NH}_{4}\right)_{2} \mathrm{SO}_{4}$, amino acids $(\mathrm{ArgHCl})$, glycerol and cyclodextrins [15-17].

In this study, screening, molecular identification and phylogenetic analysis of Hg-resistant bacteria were described on the basis of $16 \mathrm{~S}$ rDNA ribotyping and merA gene sequence. Following that, recombinant plasmid construction and expression and partial purification by $\mathrm{Ni}-$ NTA column of the transmembrane protein MerE involved in the mercury detoxification system were performed. Furthermore, the native MerE protein was purified by size exclusion chromatography (FPLC). Finally, the detoxification potential of $\mathrm{Hg}$-resistant bacteria from $\mathrm{Hg}$-contaminated wastewater was also checked.

\section{Materials and Methods}

\section{Chemicals and Expression Vectors}

For DNA restriction, the enzymes HindIII and SacI were purchased from New England Biolabs (www.neb.com) unless otherwise noted, and the oligonucleotides were synthesized by Integrated DNA Technologies (www.idtdna.com). Ligation Kit was purchased from life sciences (www.lifescience.roche.com). For bacterial genomic DNA, a GeneJET Purification Kit and E. coli cells (DH5 $\alpha$ Competent) were obtained from Thermo Fisher ( (www.thermofisher.com). Bacterial competent cells (E. coli) C43(DE3) were obtained from Lucigen(c) (www.lucigen.com). For plasmid preparations, small scale a Gel Extraction Kit (Miniprep Kit) and Ni-NTA resin were obtained from Qiagen` (www.qiagen.com). The PCR reagents were purchased from Agilent Technologies@ (www.genomics.agilent.com). Sephacryl S-200 column for size exclusion chromatography was purchased from Pharmacia LKB (USA).

\section{Isolation and Screening of $\mathbf{H g}^{\mathrm{R}}$ Bacteria}

Mercury-resistant bacteria were isolated from wastewater and contaminated soil samples obtained from the tanneries near Kasur district in Pakistan. The physico-chemical properties such as temperature, soluble salts, organic matter, $\mathrm{Hg}_{2}{ }^{+}$concentration and soluble N, P, and K, of all samples were checked. To this end, serial dilutions of $10^{-1}, 10^{-2}, 10^{-3}$, and $10^{-4}$ were prepared from $1 \%$ of the initial water and soil samples. For obtaining the isolated colonies of Hg-resistant bacteria, $100 \mu \mathrm{l}$ from the $10^{-3}$ and $100^{-4}$ dilutions were spread on Lauria Bertani (LB) agar plates supplemented with $\mathrm{HgCl}_{2}$ of different concentrations ranging from 1-200 $\mu \mathrm{M}$. The plates were incubated at $37^{\circ} \mathrm{C}$ for $24 \mathrm{~h}$. After incubation, the isolated and $\mathrm{Hg}$-resistant colonies were obtained and these were re-streaked on new LB agar plates without $\mathrm{HgCl}_{2}$ for obtaining purified colonies and stored as glycerol stocks at $-80^{\circ} \mathrm{C}$. 


\section{PCR-Amplification of $16 \mathrm{~S}$ rRNA and merA Genes}

The bacterial isolates AZ-1, AZ-2, and AZ-3 showing high resistance against $\mathrm{HgCl}_{2}$, were characterized by $16 \mathrm{~S}$ rDNA ribotyping. Bacterial strain ZA-15 was used as a negative control. The bacterial genomic DNA was extracted by GeneJET Genomic DNA Kit. The universal primers used for the amplification of $16 \mathrm{~S}$ rRNA gene were: 16S-F (5'AGAGTTTGATCCTGGCTCAG3') and 16S-R (5'AAGGAGGTGATCCAGCCGCA3') [18] and for merA gene; merAF : 5'TGGGTGGAACTTGCGTTAA3' and merAR : 5'TTATCCAGCACAGCAAGATA3' using thermal cycler. The amplification conditions for both genes consisted of initial denaturation at $95^{\circ} \mathrm{C}(5 \mathrm{~min})$ and then 30 cycles of $95^{\circ} \mathrm{C}(1 \mathrm{~min})$, $55^{\circ} \mathrm{C}(1 \mathrm{~min})$, and $72{ }^{\circ} \mathrm{C}(1.5 \mathrm{~min})$, plus an additional cycle at $72^{\circ} \mathrm{C}$ ( $5 \mathrm{~min}$ ) for chain elongation. The amplified products were sent to the Macrogen sequencing core facility in Korea and the obtained sequence results were checked by NCBI nucleotide BLAST and finally submitted to GenBank.

\section{Phylogenetic Relationship}

The multiple sequence alignment through ClustalW was used to check phylogeny among bacterial species of the Bacillus genera on the basis of $16 \mathrm{~S}$ rRNA and merA genes through the neighborjoining method using MEGA 5 software. The percentage of homology among different clades was checked with a bootstrap test at a value of 1,000 replicas as shown next to the branches. The tree is drawn to scale which represents the nucleotide change. The units of branch lengths and the evolutionary distances are the same and used to infer the phylogenetic tree.

\section{Construction and Expression of Recombinant Plasmid pHLMerE}

The merE gene of mercury-resistant isolate Bacillus cereus AZ-2 was amplified using the following primers; F-MerE [5'ATCTAT AAGCTTATGAAAAACATAATAAAAAGTTCAGGTTGGTTTCTT GTCG3'], R-MerE [5'ATATATGAGCTCTCATGACTTGAACTT CTCCATGCTGCAAC3']. Bacillus megaterium MB1 was used as a positive control for both merA and merE genes [9]. The amplified DNA of $270 \mathrm{bp}$ was cloned in HindIII-Sacl-cleaved pHLV expression vector. The designed recombinant plasmid was transformed into DH5 $\alpha$ competent cells. The pHLMerE (3,842 bp) was confirmed by restricting with the same enzymes and visualized on agarose gel electrophoresis. The nucleotide sequence of merE gene was also confirmed by a DNA sequencing facility provided by the University of California, San Diego (UCSD), USA. The recombinant plasmid pHLMerE was then transformed into E. coli competent cells C43(DE3) as described in our previous study [19].

Five $\mu$ l of clone C43(DE3):pHLMerE from glycerol stock was inoculated in $5 \mathrm{ml}$ of $\mathrm{LB}$ medium containing $50 \mathrm{mg} / \mathrm{l}$ of cabenicillin and incubated for $5 \mathrm{~h}$ at $37^{\circ} \mathrm{C}$. After incubation, $1 \mathrm{ml}$ was taken from $5 \mathrm{ml}$ culture and inoculated in $50 \mathrm{ml}$ of $\mathrm{M} 9$ minimal medium $\left(\mathrm{Na}_{2} \mathrm{HPO}_{4} 7.0 \mathrm{~g}, \mathrm{KH}_{2} \mathrm{PO}_{4} 3.0 \mathrm{~g}, \mathrm{NaCl} 0.5 \mathrm{~g}, \mathrm{CaCl}_{2}\right.$ $0.1 \mathrm{mM}, \mathrm{MgSO}_{4} 1 \mathrm{mM}$, thiamine $50 \mathrm{mg}$, D-glucose10 g, $\left(\mathrm{NH}_{4}\right)_{2} \mathrm{SO}_{4}$ $1 \mathrm{~g}$ and $50 \mathrm{mg} / \mathrm{l}$ of carbenicillin for $1 \mathrm{~L}$ ) and kept in shaking incubator at $37^{\circ} \mathrm{C}$ for overnight with $300 \mathrm{rpm}$. An overnight $50-\mathrm{ml}$ culture was poured into $450 \mathrm{ml}$ of the same M9 medium and allowed to grow at the same growth conditions. When the optical density of the culture reached at O. $D_{600} \sim 0.6$, isopropyl- $\beta$-Dthiogalactoside (IPTG) with final concentration of $1 \mathrm{mM}$ was added for the production of His-tag_trp $\Delta$ LE_thrombin site_MerE fusion protein and shaking was continued in the same incubator for another $7 \mathrm{~h}$. The cell pellet harboring recombinant plasmid was obtained by centrifugation at 7,000 $\times g$ for $30 \mathrm{~min}$ at $4^{\circ} \mathrm{C}$.

\section{Purification of the Recombinant Protein by $\mathrm{Ni}^{2+}$-NTA Column}

The purification of the recombinant protein by $\mathrm{Ni}^{2+}-\mathrm{NTA}$ column was performed by using a method as described in our previous studies with some modifications [20-22]. The cell pellet was re-suspended in $30 \mathrm{ml}$ lysis buffer consisting of $50 \mathrm{mM}$ Tris hydrochloride, $15 \%$ glycerol (v/v), $1 \mathrm{mM} \mathrm{NaN}_{3}$ with $\mathrm{pH} 8.0$ and incubated at room temperature for $10 \mathrm{~min}$. The collected cell lysate was disrupted by sonication for $5 \mathrm{~min}$ on ice $(5 \mathrm{sec} \mathrm{ON}$ and $10 \mathrm{sec}$ OFF) and spun down at $17,000 \times \mathrm{g}$ for $30 \mathrm{~min}$ at $4^{\circ} \mathrm{C}$. At this stage, purified inclusion bodies contained presumably $90 \%$ of MerE recombinant protein. The inclusion bodies were solubilized in the binding buffer consisting of $20 \mathrm{mM}$ Tris hydrochloride, $500 \mathrm{mM} \mathrm{NaCl}, 6 \mathrm{M} \mathrm{GndCl}$, and $5 \mathrm{mM}$ imidazole at $\mathrm{pH} 8.0$ by tip sonication. The cell lysate was centrifuged again at $19,000 \times g$ for $1 \mathrm{~h}$ to remove protein and lipid-associated cell debris. The $\mathrm{Ni}^{2+}-$ NTA histidine-binding resin was pre-equilibrated with binding buffer and then the supernatant was loaded onto the column. The resin was extensively washed by washing buffer consisting of $20 \mathrm{mM}$ Tris hydrochloride, $500 \mathrm{mM} \mathrm{NaCl}, 6 \mathrm{M} \mathrm{GndCl}$, and $50 \mathrm{mM}$ imidazole with $\mathrm{pH}$ 8.0. The polyhistidine-tagged fusion protein was eluted with elution buffer consisting of $20 \mathrm{mM}$ Tris hydrochloride, $500 \mathrm{mM} \mathrm{NaCl}, 6 \mathrm{M} \mathrm{GndCl}$, and $500 \mathrm{mM}$ imidazole with $\mathrm{pH}$ 8.0. The eluted polyhistidine-tagged fusion protein MerE was monitored by SDS-PAGE and then concentrated to $30 \mathrm{ml}$ by using a YM10 filter membrane containing Amicon stirred concentrator cells. The elute was dialyzed against $\mathrm{ddH} 2 \mathrm{O}$ in a $10 \mathrm{kDa}$ MWCO dialysis membrane with four water changes until the protein precipitated out of the solution and then lyophilized.

\section{Thrombin Cleavage of the Fusion Protein}

The cleavage of the fusion partner by thrombin was performed by the following method described by Das et al. [23] with some modifications. The lyophilized polypeptide was re-suspended in $30 \mathrm{ml}$ of binding buffer consisting of $20 \mathrm{mM}$ Tris $\mathrm{HCl}, 500 \mathrm{mM}$ $\mathrm{NaCl}, 1 \%$ SDS, $10 \mathrm{mM}$ imidazole, and $0.1 \%$ TCEP with $\mathrm{pH}$ 8.0, and loaded on to a $\mathrm{Ni}^{2+}$-NTA column which was pre-equilibrated by 20 bed volumes of thrombin cleavage buffer consisting of $20 \mathrm{mM}$ HEPES, $250 \mathrm{~mm} \mathrm{NaCl}, 0.1 \%$ hexadecylphosphocholine, $\mathrm{pH}$ with 8.0). The fusion partner trp $\Delta \mathrm{LE}$ was cut-off by thrombin (1000 units) by incubating for $2 \mathrm{~h}$ at room temperature. The column was then washed with 10 bed volumes of washing buffer consisting of $20 \mathrm{mM}$ Tris $\mathrm{HCl}, 0.5 \%$ dodecylphosphocholine, $50 \mathrm{mM} \mathrm{NaCl}$, and $20 \mathrm{mM}$ imidazole with $\mathrm{pH}$ 7.3). The native MerE and fusion 
partner were eluted with 3 bed volumes of elution buffer consisting of $20 \mathrm{mM} \mathrm{HEPES}, 0.5 \%$ dodecylphosphocholine, $500 \mathrm{mM}$ imidazole, and $50 \mathrm{mM} \mathrm{NaCl}$ with $\mathrm{pH}$ 7.3. Approximately 2-3 mg of MerE protein was obtained from each $10 \mathrm{ml}$ elute and lyophilized. The cleaved polypeptide was washed and precipitated by using a 3,500-kDa MWCO dialysis membrane against $\mathrm{ddH}_{2} \mathrm{O}$ and then lyophilized.

\section{Purification of MerE by FPLC}

The purification of MerE protein by FPLC was performed as described by Amin and Latif [22]. The cleaved and lyophilized MerE protein was solubilized in $5 \mathrm{ml}$ phosphate SDS buffer containing $100 \mathrm{mM} \mathrm{Na} \mathrm{HPO}_{4}, 20 \mathrm{mM}$ DTT, $4 \mathrm{mM}$ SDS, I mM EDTA, and $1 \mathrm{mM} \mathrm{NaN}_{3}$ with $\mathrm{pH}-8.2$. The aggregated protein was disturbed by extensive bath sonication which presumably incorporated SDS into micelles for maintaining stable tertiary structure. For the separation of leader peptide + His-tag from the pure MerE protein, a Pharmacia FPLC system was used containing a Sephacryl S-200 column. The column was pre-equilibrated by phosphate-SDS buffer and $5 \mathrm{ml}$ of sample was loaded. Fractions containing protein MerE were pooled and concentrated down to $30 \mathrm{ml}$ using a 3,500-kDa MWCO membrane of Amicon stirred cells. The pure MerE protein was then dialyzed against $\mathrm{ddH} 2 \mathrm{O}$ with $40 \mathrm{mM} \beta$ - mercaptoethanol to remove SDS for 6 to 12 -h changes until the protein was precipitated. The protein was quickly lyophilized and stored at $-20^{\circ} \mathrm{C}$ for further experiments. Approximately $0.5-1 \mathrm{mg}$ of MerE protein per one liter of cell culture was obtained as measured by spectrophotometer. SDSPAGE was used at each step for monitoring the purification of final native MerE protein.

\section{Detoxification of $\mathrm{Hg}^{2+}$ by Selected Bacteria at a Lab Scale}

Selected bacterial strains (AZ-1, AZ-2, AZ-3, and ZA-15) were inoculated in four flasks containing $30 \mathrm{ml}$ of wastewater containing $30 \mu \mathrm{g} / \mathrm{ml}$ of $\mathrm{HgCl}_{2}$ separately. The detoxification efficiency of mercury was determined by inoculating $1.5 \mathrm{ml}$ of overnight free cell culture (O.D. 2.0 at $600 \mathrm{~nm}$ ) in four flasks ( $4^{\text {th }}$ flask was taken as control) in triplicates and incubated at $37^{\circ} \mathrm{C}$ for $24 \mathrm{~h}$ at $120 \times g$ of agitation. After incubation, cultures were centrifuged at $14,000 \times g$ for $15 \mathrm{~min}$ and the supernatant was separated. The $\mathrm{pH}$ of supernatant for each strain was adjusted to 0.4 by adding concentrated $\mathrm{H}_{2} \mathrm{SO}_{4}$ and then transferred to a separating funnel. To the cooled solution, $4 \mathrm{ml}$ of $6 \mathrm{~N}$ acetic acid and $2.5 \mathrm{ml}$ chloroform were added and vigorously shaked for $1 \mathrm{~min}$. The phases were allowed to separate completely before the chloroform layer was taken out and discarded. Freshly prepared $5 \mathrm{ml}$ of $0.001 \%$ dithizone solution was added in the remaining solution of each strain and again shaked vigorously for $1 \mathrm{~min}$. The layers were allowed to separate and cotton was placed in the tips of separating funnels to elute the dithizone-mercury complex. In the absence of mercury $\left(\mathrm{Hg}^{+}\right)$no significant color was extracted into dithizone, while in the presence of $\mathrm{Hg}^{+}$, an orange color was observed in the organic layer, and the color became more pronounced with higher concentration of $\mathrm{Hg}^{+}$. The optical density (O.D) of water-free chloroform extracts was determined at $500 \mathrm{~nm}$ against reagent (dithizone) blank to estimate the detoxification of $\mathrm{Hg}^{2+}[24,25]$.

\section{Statistical Analysis}

All statistical analyses i.e., mean, standard deviation and analysis of variance (ANOVA) of this lab scale mercury detoxification experiment were performed by using SPSS V.20 software.

\section{Results and Discussion}

The interaction between heavy metals and heavy metalresistant microorganisms has been determined by bacterial transformation and the conversion of metallic ion forms to elemental forms by reduction [26]. Some of these microorganisms have shown promising activity to decrease mercury in contaminated environments. In the present study, three bacterial strains out of 30 were selected on the basis of resistance to higher $\mathrm{HgCl}_{2}$ concentrations (MIC: up to $1-200 \mu \mathrm{M})$ and two strains, ZA-15 and MB1 were used as negative and positive controls respectively (Table 1).

The physicochemical parameters of selected samples at the time of collection were checked as temperature $24^{\circ} \mathrm{C}$, $\mathrm{pH} 8.2$, soluble salts $0.7 \mathrm{~g} / \mathrm{kg}$, organic matter $8.4 \mathrm{~g} / \mathrm{kg}$, $\mathrm{Hg}_{2}{ }^{+}$concentration $10-20 \mu \mathrm{g} / \mathrm{ml}$, soluble $\mathrm{N}, \mathrm{P}$ and $\mathrm{K} 53.5$, 3.5 , and $45 \mathrm{mg} / \mathrm{kg}$. In literature, $100 \mu \mathrm{M}, 50 \mathrm{ppm}$ and $100 \mu \mathrm{g} / \mathrm{ml}$ were found to be the MIC for mercury in Bacillus spp. [27-29].

Mercury-resistant bacterial isolates (AZ-1, AZ-2, and AZ3) were characterized by $16 \mathrm{~S}$ rDNA ribotyping $(\approx 1.5 \mathrm{~kb})$ and identified as Bacillus sp. (KT270477), Bacillus cereus (KT270478), and Bacillus cereus (KT270479), respectively. Other close matches to Bacillus sp. (KT270477) included Bacillus anthracis HQ200405 and Bacillus sp. JN593078 and GU566355. The bacterial isolates also showed similarity (98\%) among themselves. In the same clade, B. cereus AZ-1 and AZ-2 showed $98 \%$ similarity with already reported

Table 1. Growth of bacterial strains at different concentrations of $\mathrm{HgCl}_{2}$.

\begin{tabular}{lcccc}
\hline \multirow{2}{*}{ Isolates } & \multicolumn{5}{c}{ Growth against $\mathrm{HgCl}_{2}(\mu \mathrm{g} / \mathrm{ml})$} \\
\cline { 2 - 5 } & 10 & 20 & 30 & 40 \\
\hline $\mathrm{AZ}-1$ & + & + & + & + \\
$\mathrm{AZ}-2$ & + & + & + & + \\
$\mathrm{AZ}-3$ & + & + & + & + \\
ZA-15 (-ve control) & - & - & - & - \\
MB1 (+ve control) & + & + & + & + \\
\hline
\end{tabular}




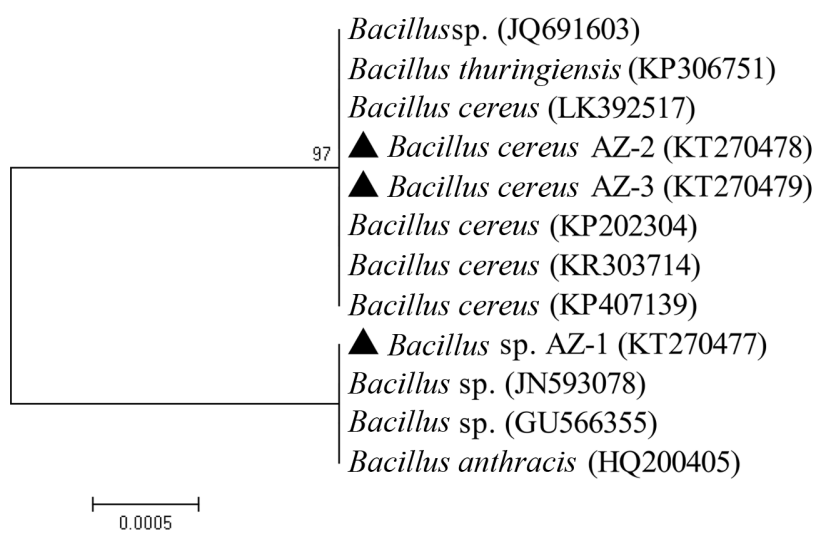

Fig. 1. Evolutionary relationships of different Bacillus sp. on the basis of $16 \mathrm{~S}$ rDNA ribotyping.

B. thuringiensis KP306751, Bacillus sp. JQ691603 and B. cereus KP407139, KR303714, KP202304 and LK392517 (Fig. 1).

Phylogenetic analysis of selected bacterial strains on the basis of merA gene showed 100\% homology with already reported sequences of merA genes in B. cereus NG034957, B. megaterium NG035056, Bacillus sp. LC015492, Paenibacillus sp. LC015492, 98\% in B. macroides Y09906, 89\% in Bacillus sp. RC607 AF138877 and Clostridium butyricum AB024961 and $88 \%$ in B. cereus AB066362 and also with themselves (Fig. 2).

The gene construct containing merE was designed by modifying previously reported $\mathrm{pHLV}$ pu plasmid constructed by pHLV_ML vector which is derivative of the commonly used vector pET-3a [30]. The vector consisted of 9-His-tagtryptophan-leader-Vpu fusion on plasmid encoding carbenicillin resistance. In modified vector, $\mathrm{Vpu}$ gene was replaced by merE gene by designing specific primers as shown in Fig. 3A. In the gene construct, His-tag and Trpleader peptide sequences were inserted for the ease of purification and the formation of inclusion bodies respectively. The recombinant plasmid was transformed into competent $\mathrm{DH} 5 \alpha$ and amplified in LB medium. The plasmid was then transformed into E. coli C43(DE3) cells for producing high yield of MerE recombinant protein. The fusion protein was found non-toxic to C43(DE3) cells and expressed at levels up to approximately $20 \%$ of total cellular protein.

After expression, the separation and purification of MerE were performed. Briefly, the inclusion bodies containing recombinant/fusion protein were separated from the total cell lysate by centrifugation. The fusion protein was partially purified by nickel affinity chromatography and dialyzed to decrease gradually the denaturant concentration for efficient protein refolding. The data in Fig. 4 illustrated the expression and isolation of inclusion bodies of fulllength recombinant MerE by $\mathrm{Ni}^{2+}$-NTA column. During dialysis, the protein refolding activity of chemically denatured protein was increased sufficiently due to the decrease in denaturant concentration. The protein concentrations remained almost constant during the refolding process. The rate of refolding to the native (active) structure was also increased by increasing dialyzing

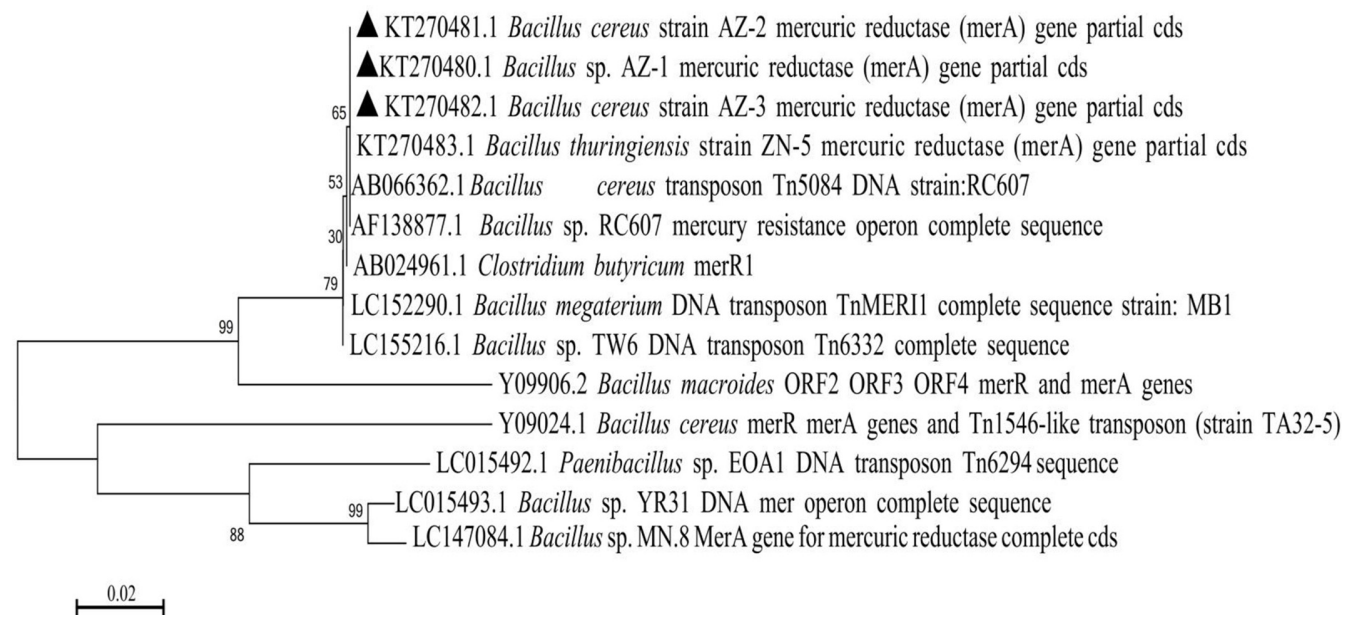

Fig. 2. Evolutionary relationship of different Bacillus sp. on the basis of merA gene was inferred using the Neighbor-Joining method with the sum of branch length 0.53623375 .

The branch lengths and the evolutionary distances used to infer the phylogenetic tree are in the same units with the bootstrap test value 500 . The analysis involved 17 nucleotide sequences and codon positions included were 1 st+2nd+3rd+Noncoding. A total of 1279 positions were in the final dataset with no gaps and missing data. Evolutionary analyses were performed by MEGA 5 software [42]. 
A

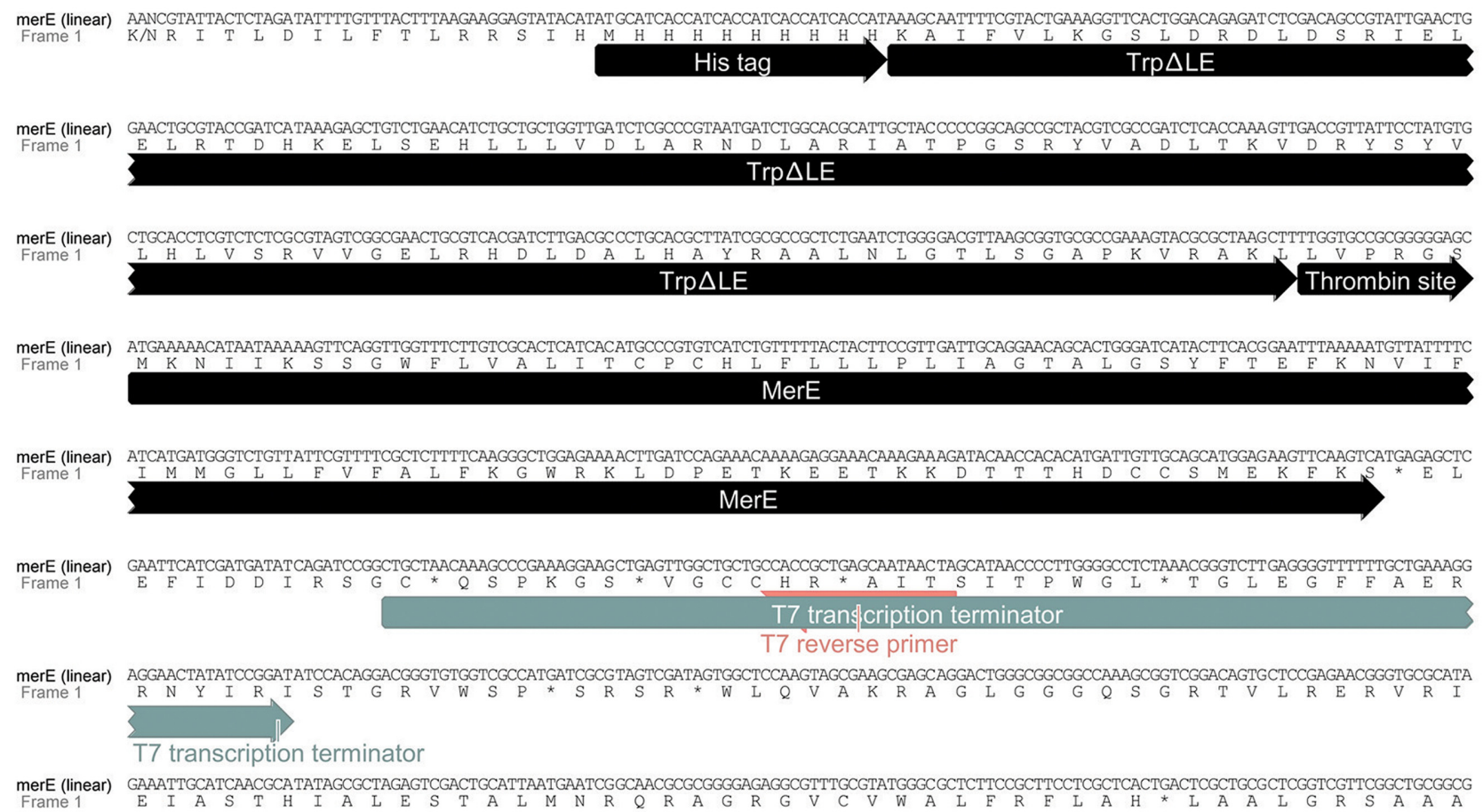

merE (linear)

GAAATTGCATCAACGCATATAGCGCTAGAGTCGACTGCATTAATGAATCGGCAACGCGCGGGGAGAGGCGTTTGCGTATGGGCGCTCTTCCGCTTCCTCGCTCACTGACTCGCTGCGCTCGGTCGTTCGGCTGCGGCG

B

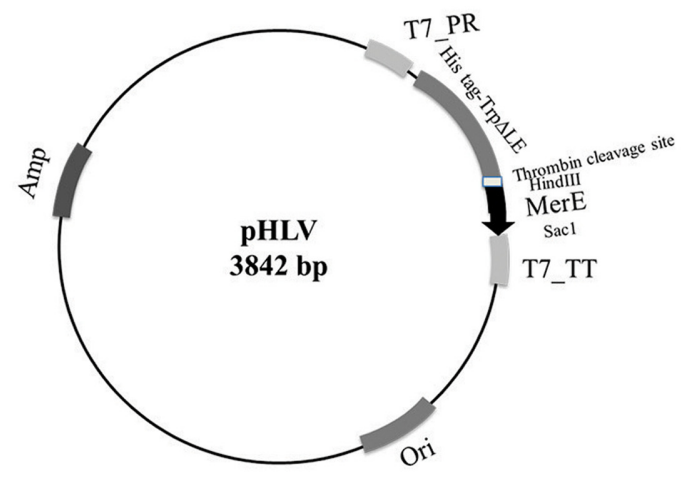

$\mathrm{Gr}+\mathrm{ve}$ (AZ-2)- MKNIIKSSGWFLVALITCPCHLFLLLPLIAGTALGSYFTEFKNVIFIMMGLLFVFALFKGWRKLDPETKEETKKDTTTHDCCSMEKFKS

$\mathrm{Gr}$-ve- MNAPDKLPPETRQPVSGYLWGALAVLTCPCHLPILAAVLAGTTAGAFLGEHWGVAALALT GLFVLAVTRLLRAFRGGS

Fig. 3. (A) The pHLV plasmid; in linear form showing nucleotide and amino acid sequences of His-tag, fusion partner, thrombin site and MerE while in circular form showing T7 promoter, T7 terminator, His-tag_trp $\Delta$ LE_thrombin site_MerE, HindIII and SacI restriction sites, ori and selection marker (B) Amino acid sequences of MerE polypeptides in Gram-positive and Gram-negative bacteria.

time along with the decrease in concentration of denaturant $[15,31]$.

After elution by nickel column, the targeted fusion protein was solubilized in thrombin cleavage buffer and again bound to the affinity column for cleaving native MerE from fusion partner (Trp $\Delta \mathrm{LE}$ ) and dialyzed. Lane 2 in Fig. 5A showed the cleavage of fusion protein and lane 3 contained the impurified fraction of MerE while lanes 4-7 showed the purified fractions of native MerE after sizeexclusion chromatography (FPLC). Fig. 5B showed the peaks of MerE and Trp $\Delta$ LE in FPLC equipped with a Sephacryl S-200 HR column. The fully denatured proteins by $\mathrm{GndCl}$ or urea, usually have a high tendency to aggregate due to the exposure of buried hydrophobic residues. The gel filtration column used for SEC/FPLC restricts the aggregation by physically isolating the molecules 


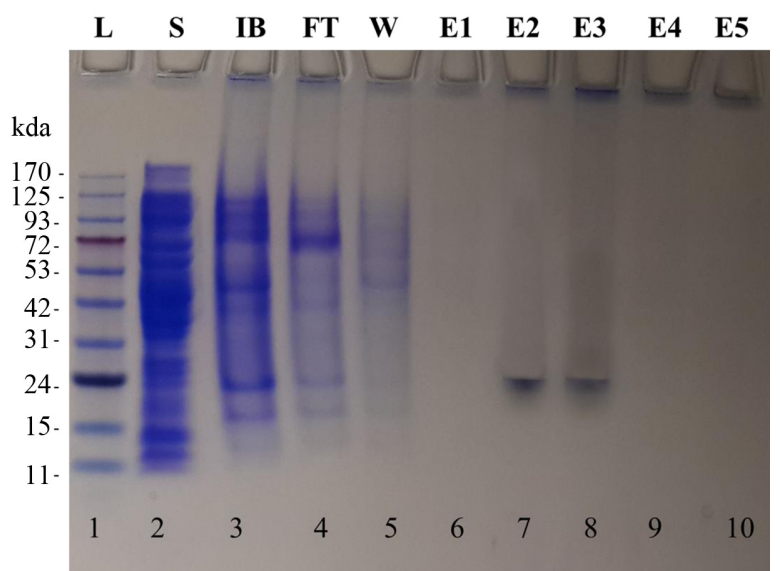

Fig. 4. SDS-PAGE of MerE fusion protein.

L (lane 1): AccuRuler pre-stained protein ladder (kDa). S (lane 2): supernatant containing approximately the total cellular proteins. IB (lane 3): inclusion bodies containing recombinant plasmid. FT (lane 4): flow through as soluble fractions of lysate. W (lane 5): washing of cellular proteins except protein of interest (targeted). E1-E5 (lane 610): elutes of inclusion bodies containing recombinant protein.

and allows the successful recovery of biologically active (refolded) proteins. Using this approach, Neely et al. [32]
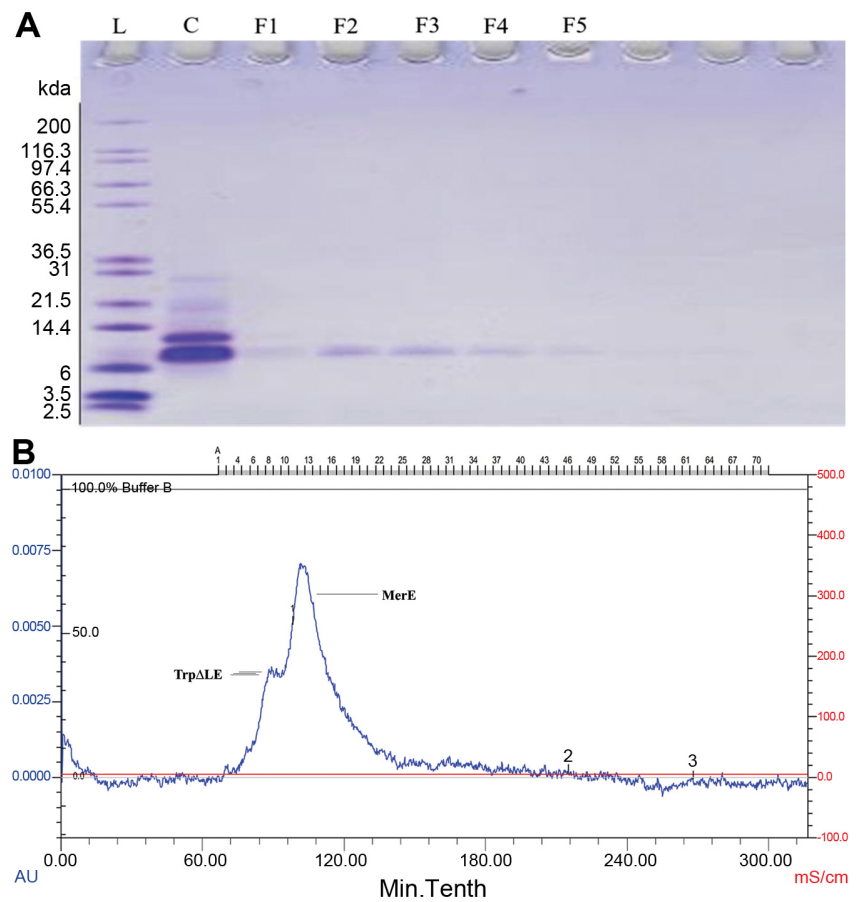

Fig. 5. (A) SDS-PAGE of native protein MerE and fusion partner $\operatorname{Trp} \Delta \mathrm{LE}$ after cleavage by thrombin. L: ladder $(\mathrm{kDa})$. C: cleavage by thrombin. F1-F5: fractions of native MerE from Sephacryl S-200 column. (B) SEC chromatogram showing peaks of MerE and Trp $\Delta$ LE. successfully obtained refolded/active $\beta_{1 b}$ subunit of a calcium channel. In a similar way, SEC refolding was successfully used to obtain biologically active forms of the $\alpha 5$ subunit of the $20 \mathrm{~S}$ proteasome from human [33]. In another example, Ouellette et al. [34] used denatured inclusion bodies of human interleukin (IL)-7 to load onto a Superdex 200 column and obtained its biologically active (refolded) form.

This was a first study for reporting the plasmid construction, expression and purification of MerE protein from Gram-positive Bacillus cereus AZ-2. Previously, Sone et al. [35] had reported the expression and preliminary purification by Nickel agarose column of MerE protein from Gram-negative bacteria. Park SH, Opella SJ [36] and Lu et al. [37] had also performed NMR structural studies of purified samples of MerE from Gram-negative bacteria. The gene and protein sequences of MerE of both types of bacteria were totally different as shown in Fig. 6. In Grampositive bacteria, the polypeptide consisted of 89 amino acids with internal methionine residues at different sites while in Gram-negative bacteria, 78 amino acids containing peptide had only single methionine at N-terminal. Due to the presence of internal methionine residues, the gene construction, expression and cleavage of recombinant protein for obtaining the native sequence of MerE varied

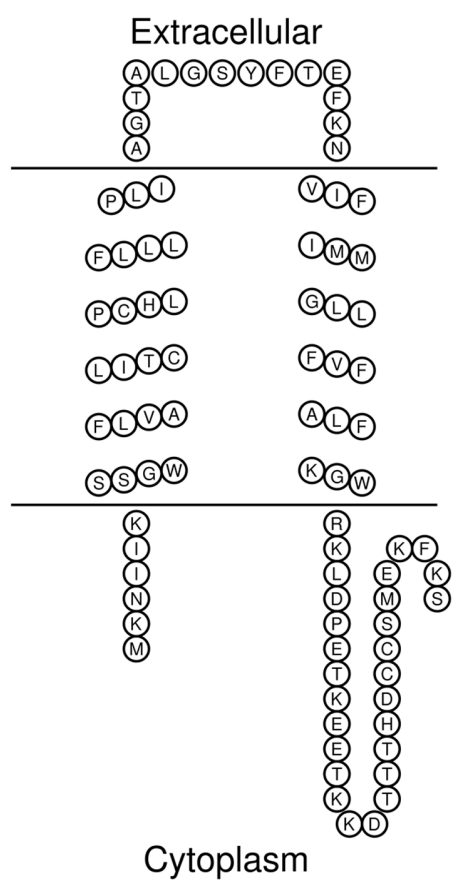

Fig. 6. Topological alignment of all amino acids of MerE separated according to the predicted hydrophobic elements generatrated by TMHMM software. 


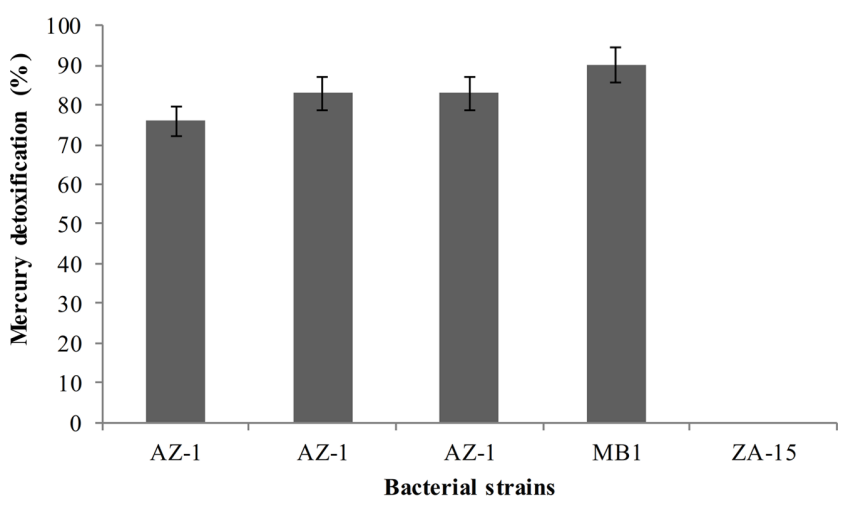

Fig. 7. Detoxification of $\mathrm{Hg}^{2+}$ by mercury-resistant bacterial strains $(p<0.05)$.

comparative to previous reports as shown in Fig. 3B. Topological alignment of all amino acids of MerE separated according to the predicted hydrophobic (membranespanning) elements is shown in Fig. 6.

It was reported that certain species such as cyanobacteria, Klebsiella aerogenes, K. aerogenes NCTC418 and Pseudomonas putida were involved in bioreduction of toxic mercury compounds under laboratory conditions [38, 39]. Nakamura K, Hagimine M, Sakai M and Furukawa K [40] reported the decrease of mercury from various mercury compounds like mercuric chloride $\left(\mathrm{HgCl}_{2}\right)$ 88.9\%, methyl mercuric chloride (MeHg) 95.4\%, ethylmercuric chloride (EtHg) 83.8\%, thimerosal $91.9 \%$, fluorescein mercuric acetate $\left(\mathrm{FMA}^{\star}\right) 74.6 \%$, phenylmercuric acetate (PMA) 5.7\%, and p-chloromercuric benzoate (p-CMB) $92.3 \%$ by Pseudoalteromonas haloplanktis strain M-1. The biosorption capability of the immobilized B. cereus cells was described by Sinha A, Pant KK, Khare SK [41] as $104.1 \mathrm{mg} / \mathrm{g} \mathrm{Hg}^{2+}$ at $30^{\circ} \mathrm{C}$ and $\mathrm{pH} \mathrm{7.0,} \mathrm{biomass}$ concentration of $0.02 \mathrm{~g} / 1$ and contact time of $72 \mathrm{~h}$. A lab scale experiment was designed to analyze the detoxification potential of mercury by selected bacterial strains. Results indicated $23(76 \%), 25(83 \%), 25(83 \%)$ and $27(90 \%) \mu \mathrm{g} / \mathrm{ml}$ detoxification of $\mathrm{Hg}^{2+}$ out of $30 \mu \mathrm{g} / \mathrm{ml}(100 \%)$ by selected bacterial strains as Bacillus sp. AZ-1, B. cereus AZ-2, B. cereus AZ-3 and E. cloacae ZA-15 respectively (Fig. 7). In conclusion, phylogenetically similar and mer operonharboring mercury-resistant bacterial strains B. cereus AZ2 , B. cereus AZ-3 can be used for the detoxification of mercury from industrial effluent.

\section{Acknowledgments}

Aatif Amin cloned the plasmid, expressed and purified the MerE protein under the supervision of Stanley J.
Opella. Arslan Sarwar and Mushtaq A. Saleem helped to execute mercury detoxification experiments and then also wrote the draft. Zakia Latif as a my supervisor, proofread the manuscript.

\section{Conflict of interest}

The authors declare that they have no conflict of interest.

\section{References}

1. Steenhuisen F, Wilson SJ. 2015. Identifying and characterizing major emission point sources as a basis for geospatial distribution of mercury emissions inventories. Atmos. Environ. 112: $167-177$.

2. Santos-Gandelman JF, Giambiagi-deMarval M, Muricy G, Barkay T, Laport MS. 2014. Mercury and methylmercury detoxification potential by sponge-associated bacteria. Antonie Leeuwenhoek 106: 585-590.

3. Abbas Z, Chaudary MN, Raza A, Mehmood A. 2012. Toxicity of mercury in different samples (water and soils) and its exposure in pakistan. Sci. Int. 24: 421-429.

4. Sedlmeier R, Altenbuchner J. 1992. Cloning and DNA sequence analysis of the mercury resistance genes of Streptomyces lividans. Mol. Gen. Genet. 236: 76-85.

5. Nakamura K, Silver S. 1994. Molecular analysis of mercuryresistant Bacillus isolates from sediment of Minamata Bay, Japan. Appl. Environ. Microbiol. 60: 4596-4599.

6. Bogdanova E, Bass I, Minakhin L, Petrova M, Mindlin S, Volodin A, et al. 1998. Horizontal spread of mer operons among Gram-positive bacteria in natural environments. Microbiology 144: 609-620.

7. Lund PA, Ford SJ, Brown NL. 1986. Transcriptional regulation of the mercury-resistance genes of transposon Tn501. J. Gen. Microbiol. 132: 465-480.

8. Moore MJ, Distefano MD, Zydowsky LD, Cummings RT, Walsh CT. 1990. Organomercurial lyase and mercuric ion reductase: nature's mercury detoxification catalysts. Acc. Chem. Res. 23: 301-308.

9. Huang CC, Narita M, Yamagata T, Endo G. 1999. Identification of three mer $B$ genes and characterization of a broad-spectrum mercury resistance module encoded by a class II transposon of Bacillus megaterium strain MB1. Gene 239: 361-366.

10. Hamlett N, Landale E, Davis B, Summers A. 1992. Roles of the Tn21 merT, merP, and merC gene products in mercury resistance and mercury binding. J. Bacteriol. 174: 6377-6385.

11. Barkay T, Miller SM, Summers AO. 2003. Bacterial mercury resistance from atoms to ecosystems. FEMS Microbiol. Rev. 27: 355-384.

12. Kiyono M, Sone $\mathrm{Y}$, Nakamura R, Pan-Hou H, Sakabe K. 2009. The MerE protein encoded by transposon $\operatorname{Tn} 21$ is a 
broad mercury transporter in Escherichia coli. FEBS Lett. 583: $1127-1131$.

13. Baneyx F, Mujacic M. 2004. Recombinant protein folding and misfolding in Escherichia coli. Nat. Biotechnol. 22: 1399.

14. Li M, Su Z-G, Janson J-C. 2004. In vitro protein refolding by chromatographic procedures. Protein Expr. Purif. 33: 1-10.

15. Tsumoto K, Ejima D, Kumagai I, Arakawa T. 2003. Practical considerations in refolding proteins from inclusion bodies. Protein Expr. Purif. 28: 1-8.

16. Yamaguchi H, Miyazaki M. 2014. Refolding techniques for recovering biologically active recombinant proteins from inclusion bodies. Biomolecules 4: 235-251.

17. Bajorunaite E, Cirkovas A, Radzevicius K, Larsen KL, Sereikaite J, Bumelis V-A. 2009. Anti-aggregatory effect of cyclodextrins in the refolding process of recombinant growth hormones from Escherichia coli inclusion bodies. Int. J. Biol. Macromol. 44: 428-434.

18. Normand P. 1995. Utilisation des séquences $16 \mathrm{~S}$ pour le positionnement phylétique d'un organisme inconnu. Oceanis 21: 31-56.

19. Amin A, Latif Z. 2017. Screening of mercury-resistant and indole-3-acetic acid producing bacterial-consortium for growth promotion of Cicer arietinum L. J. Basic Microbiol. 57: 204-217.

20. Park SH, Das BB, Casagrande F, Tian Y, Nothnagel HJ, Chu M, et al. 2012. Structure of the chemokine receptor CXCR1 in phospholipid bilayers. Nature 491: 779.

21. Cook GA, Stefer S, Opella SJ. 2011. Expression and purification of the membrane protein $\mathrm{p} 7$ from hepatitis $\mathrm{C}$ virus. J. Pept. Sci. 96: 32-40.

22. Amin A, Latif Z. 2017. Cloning, expression, isotope labeling, and purification of transmembrane protein MerF from mercury resistant Enterobacter sp. AZ-15 for NMR studies. Front. Microbiol. 8: 1250.

23. Das BB, Park SH, Opella SJ. 2015. Membrane protein structure from rotational diffusion. Biochim. Biophys. Acta (BBA)-Biomembr. 1848: 229-245.

24. Elly CT. 1973. Dithizone procedure for mercury analysis. J. Water Pollut. Control Fed. 940-945.

25. Humaira K, Mohammad J, Mohammad I. 2005. A simple spectrophotometric determination of trace level mercury using 1,5-diphenylthiocarbazone solubilized in micelle. Anal. Sci. 21: 507-512.

26. Chang JS, Huang JC. 1998. Selective adsorption/recovery of $\mathrm{Pb}, \mathrm{Cu}$, and $\mathrm{Cd}$ with multiple fixed beds containing immobilized bacterial biomass. Biotechnol. Prog. 14: 735-741.

27. Sathyavathi S, Manjula A, Rajendhran J, Gunasekaran P. 2013. Biosynthesis and characterization of mercury sulphide nanoparticles produced by Bacillus cereus MRS-1. Indian J. Exp. Biol. 51: 973-978.

28. Santos-Gandelman JF, Cruz K, Crane S, Muricy G, Giambiagi-deMarval M, Barkay T, et al. 2014. Potential application in mercury bioremediation of a marine spongeisolated Bacillus cereus strain Pj1. Curr. Microbiol. 69: 374-380.
29. Dash HR, Das S. 2015. Bioremediation of inorganic mercury through volatilization and biosorption by transgenic Bacillus cereus BW-03 (PW-05). Int. Biodeterior. Biodegrad. 103: 179-185.

30. Ma C, Marassi FM, Jones DH, Straus SK, Bour S, Strebel K, et al. 2002. Expression, purification, and activities of fulllength and truncated versions of the integral membrane protein Vpu from HIV-1. Protein Sci. 11: 546-557.

31. Clark EDB. 2001. Protein refolding for industrial processes. Curr. Opin. Biotechnol. 12: 202-207.

32. Neely A, Garcia-Olivares J, Voswinkel S, Horstkott H, Hidalgo P. 2004. Folding of active calcium channel $\beta 1 \mathrm{~b}-$ subunit by size-exclusion chromatography and its role on channel function. J. Biol. Chem. 279: 21689-21694.

33. Han Y-G, Liu H-L, Zheng H-J, Li S-G, Bi R-C. 2004. Purification and refolding of human $\alpha 5$-subunit (PSMA5) of the $20 \mathrm{~S}$ proteasome, expressed as inclusion bodies in Escherichia coli. Protein Expr. Purif. 35: 360-365.

34. Ouellette T, Destrau S, Ouellette T, Zhu J, Roach JM, Coffman JD, et al. 2003. Production and purification of refolded recombinant human IL-7 from inclusion bodies. Protein Expr. Purif. 30: 156-166.

35. Sone Y, Nakamura R, Pan-Hou H, Sato MH, Itoh T, Kiyono M. 2013. Increase methylmercury accumulation in Arabidopsis thaliana expressing bacterial broad-spectrum mercury transporter MerE. AMB Express. 3: 52.

36. Park SH, Opella SJ. 2010. Triton X-100 as the "short-chain lipid" improves the magnetic alignment and stability of membrane proteins in phosphatidylcholine bilayers for oriented-sample solid-state NMR spectroscopy. J. Am. Chem. Soc. 132: 12552-12553.

37. Lu GJ, Son WS, Opella SJ. 2011. A general assignment method for oriented sample (OS) solid-state NMR of proteins based on the correlation of resonances through heteronuclear dipolar couplings in samples aligned parallel and perpendicular to the magnetic field. J. Magn. Reson. 209: 195-206.

38. Glendinning K, Macaskie L, Brown N. 2005. Mercury tolerance of thermophilic Bacillus sp. and Ureibacillus sp. Biotechnol. Lett. 27: 1657-1662.

39. Oehmen A, Fradinho J, Serra S, Carvalho G, Capelo J, Velizarov S, et al. 2009. The effect of carbon source on the biological reduction of ionic mercury. J. Hazard. Mater. 165: 1040-1048.

40. Nakamura K, Hagimine M, Sakai M, Furukawa K. 1999. Removal of mercury from mercury-contaminated sediments using a combined method of chemical leaching and volatilization of mercury by bacteria. Biodegradation 10: 443447.

41. Sinha A, Pant KK, Khare SK. 2012. Studies on mercury bioremediation by alginate immobilized mercury tolerant Bacillus cereus cells. Int. Biodeterior. Biodegradation 71: 1-8.

42. Tamura K, Nei M, Kumar S. 2004. Prospects for inferring very large phylogenies by using the neighbor-joining method. Proc. Natl. Acad. Sci. USA 101: 11030-11035. 